\title{
Taming the wild west of business coaching training: An emerging conceptual framework
}

\begin{abstract}
Author:
Jeanette Maritz

Affiliation:

${ }^{1}$ University of South Africa,

South Africa

Correspondence to:

Jeanette Maritz

Email:

maritje@unisa.co.za

Postal address:

PO Box 392, UNISA 0003,

South Africa

Dates:

Received: 31 Jan. 2013

Accepted: 28 Mar. 2013

Published: 10 May 2013

How to cite this article:

Maritz, J., 2013, 'Taming

the wild west of business

coaching training: An

emerging conceptual

framework', Acta Commerci

13(1), Art. \#174, 11 pages.

http://dx.doi.org/10.4102/

ac.v13i1.174
\end{abstract}

\section{Copyright:}

(C) 2013. The Authors

Licensee: AOSIS

OpenJournals. This work

is licensed under the

Creative Commons

Attribution License.
Orientation: Although it is believed that business coaching provides a positive intervention in building and supporting management capability, there has been little empirical research into the frameworks that could be applied in business coach training in the South African context.

Purpose: The purpose of this study was to explore and describe an emerging conceptual framework for business coach training programmes.

Motivation of the study: An empirical void existed in coach training pedagogy with regard to business coach training programmes.

Research design, approach and method: A qualitative, design was used to describe and understand the needs of business coaching stakeholders. Data were collected by means of focus groups, individual interviews and naïve sketches from business coach stakeholders such as the purchasers of coaching, coach educators, coachees $(n=30)$. Data were analysed using a thematic approach.

Main findings: The findings were conceptualised and described in terms of the business coach educator as a role model and facilitator of learning, the business coach learner as an adult learner and the educational context. An appreciative environment was recommended. The procedure suggested a progressive broadening of knowledge and skills in an outcomesbased education model. The outcome envisioned a competent business coach who practises both ethically and competently.

Practical/managerial implications: A key prerequisite for the future of business coach training programmes should be a coaching curriculum that is embedded in empirical research, with well-defined theoretical frameworks that guide coaching training and practice.

Contribution/value-add: An emerging conceptual framework for business coach training programmes was described that could stimulate debate on what should matter in business coach training.

\section{Introduction}

Business coaching in the global marketplace is reaching maturity (De Haan 2008). In South Africa, however, business coaching is still in its infancy owing to the isolation of South Africa from mainstream professional development during the apartheid years. According to the Global Coaching Survey 2008 and 2009 (Bresser 2009), there are approximately 44000 business coaches operating worldwide. South Africa ranks seventh in the top ten countries with the highest number of coaches. Although the top seven countries (namely, the United States of America, the United Kingdom, Germany, Australia, Japan, Canada and South Africa) comprise only $10 \%$ of the world's population, $73 \%$ of business coaches are situated in these countries, making South Africa one of the largest operators in the business coaching environment.

Difficulties in the South African business coaching market stem from there being too small a pool of diverse, qualified and experienced business coaches to satisfy the growing organisational needs (Stout Rostron 2009). The need for business coach training is therefore proliferating as the coaching market attempts to respond to the demand.

In 2004, Sherman and Freas compared 'executive' coaching to the Wild West of the past. The business coaching and business coach training industries are currently unregulated, lack standardisation or clarity on training (Bono et al. 2009) and could, in fact, be compared to Sherman and Freas's (2004) Wild West metaphor, in that everyone is doing it, but everyone does it differently.

Purchasers of business coach training can currently choose from a diverse range of training offerings - from basic coaching certificates and refresher courses, to executive programmes, 
master's and doctoral degrees (Moore 2007). Courses on the topic of coaching are also becoming increasingly popular in academia, as degree programmes are adding to their curricula courses on leadership coaching or executive coaching. Such courses range from undergraduate psychology and business courses to MBAs (Auerbach 2005; Butler \& Forbes 2008; Laff 2007). More organisations such as Virgin, Vodacom and the like, are providing in-house business coach training in the workplace (Wilson 2004). Business institutes such as the University of Cape Town's Graduate School of Business, the University of Stellenbosch Business School, the Tshwane University of Technology and Henley Business School also offer business coach training programmes. A number of local organisations offer business coach training programmes ranging from two days to 18 months in length. Some programmes are accredited with the International Coach Federation (ICF), others with the national Services Seta and some with both. Certain programmes are underwritten by university graduate schools of business in an attempt to underscore both academic rigour and coaching practice. Courses are mostly at level 5 of the National Qualifications Framework (NQF) and vary between eight to 22 credits. The costs of these programmes vary between R24 000 and R94 000.

The International Coach Federation (ICF) has a global membership of more than 19000 members, including 9000 credentialed coaches, in more than 100 countries (ICF 2011a). A number of other international bodies include the International Coaching Council (ICC), the Worldwide Association of Business (WAB), the International Association of Coaching (IAC), the Society of Coaching Psychology (SCP) and the European Mentoring and Coaching Council (EMCC). The IAC, ICF and EMCC have recently announced a new global alliance designed to advance the professional coaching industry (e.releases 2012).

The local industry body, Coaches and Mentors Association of South Africa's (COMENSA) is the largest professional body for coaches and mentors in South Africa. Its mission is to create an umbrella association in South Africa to provide for the regulation of local coaching and to build alliances between the purchasers of providers of coaching services. A core function of COMENSA is to be involved in the area of business coaching (COMENSA 2012a).

As of 30 November 2012, COMENSA had 1262 members (Anon 2012). There are currently 41 coaching training institutions registered with COMENSA. The organisation is currently applying to register as a professional body with the South African Qualifications Authority (SAQA) (COMENSA 2012b). A Google search of business coaching training institutions in South Africa reveals many organisations that are not registered with any governing body that deliver a wide range of courses at foundation, intermediate and practitioner level.

According to Grant (2004), those who employ business coaches and potential students of business coaching are becoming more sophisticated and better informed, seeking an articulation of the underpinning theoretical frameworks. As with many emerging disciplines, however, practice precedes the establishment of sound and theoretical foundations. Bono et al. (2009) found that coaching has received more attention in the practitioner community than amongst academics. Rigorous peer-reviewed empirical work, however, is starting to emerge, but is still not that common. A key prerequisite for the future of business coach training programmes should be a coaching curriculum that is embedded in empirical research, with well-defined theoretical frameworks that guide business coaching training and practice.

\section{Theoretical background Where does coaching fit into business?}

South Africa faces a double transitional challenge - to redress the historical inequalities by building a democracy based on human rights and tolerance, and to develop simultaneously and speedily its human capital to compete in a harsh global economy (Horwitz \& Jain 2008:120).

The growing demands on 21st-century organisations has put a great deal of pressure on executives, managers and human resources to perform within national and international imperatives. Business executives and managers are often promoted on the basis of job-specific expertise without the emotional intelligence and work-life balance skills necessary to sustain their performance and productivity (Sherman \& Freas 2004; Van Jaarsveld 2004). According to O'Shaughnessy (2001), the higher up the skills hierarchy one moves, the more important marginal improvements in performance become.

Developing management is at the heart of South African progress (Tuck 2004, 2005). There are unique pressures in South Africa, as South Africa is a crucible of multicultural societies. The country's socio-political imperative of redressing past structural inequalities of access to skilled, professional and managerial positions and ownership opportunities makes unique demands on developmental offerings (Horwitz \& Jain 2008). The shortage of managerial skills, socioeconomic and labour market issues poses pressing managerial and business challenges.

In the past, those who were appointed to executive and management positions had spent years being groomed and trained, assimilating the unwritten rules, absorbing the politics, establishing networks of contacts and adjusting to changing power balances (Hillary 2003). At present, a new category of executive and manager is emerging - one who is often fast-tracked and unschooled in the unspoken, unwritten codes of conduct, with expectations unmatched with the harsh reality of the business environment (Rothgiesser 2004). Such managers are often naïve, ambitious and hopeful, but also fearful of making mistakes and being found wanting. This could lead to unnecessary distress, hurt and frustration which might result in slow personal growth and development. Unskilled managers may sap workplace 
morale, leading to higher rates of staff turnover (Kelman 2010). In addition, unskilled managers may be reckless in their decision making and not understand the extent or the implications of their decisions, costing the organisation many times the individual's salary in direct or indirect costs (Gentry, Mondore \& Brennan 2007). This could have a negative impact on business profits and costs.

Fortunately, companies are beginning to realise that executives and managers with years of training are a scarce resource and newly-promoted executives and managers need to be developed and nurtured. Their continuing wellbeing and development are critical strategic concerns. It is at this juncture that business coaching enters the arena.

Coaching stands alongside counselling and mentoring as a helping profession (Stec 2012). In the field of management, coaching focused originally on correcting deficiencies. Of late, however, it has become associated increasingly with peak performance (Stout Rostron 2009).

Business coaching is the process of engaging in regular, structured conversations with a client (individual or team) in a business, profit or non-profit organisation, institution or government, who is the recipient of business coaching. The goal is to enhance the client's awareness and behaviour in order to achieve objectives for the client and the organisation alike (World Association of Business Coaches [WABC] 2011). The business coaching process may take on different forms and involves different goals, but there is a clear focus throughout such a process for the client, as well as the organisations. Business coaching is distinct from business consulting in that the consultant positions him- or herself to fulfil more of an advisory role in order to help the client achieve the stated goals. The consultant is typically an expert in a particular field who is expected to provide answers to issues. The approach is directive, with the consultant in the position of power and influence (Smith, Van Vuuren \& Visser 2003). The coach, however, is a catalyst for change (Laff 2007). The coach uses the workplace as a classroom, facilitating the learning process and encouraging the client to learn for him- or herself (Redshaw 2000). The coach acts as a guide as opposed to an expert. The process is therefore less directive, relying on skilful questioning in order for the client to find his or her own solutions (Clegg et al. 2005). The dynamic of the process is to move the client to a position of seeing new possibilities and to generate alternative options or behaviours from which they can choose for themselves (O'Flaherty \& Everson 2005). Business coaching should culminate in a developmental journey for both the client and the coach (De Haan 2008).

\section{Everyone is doing it, and everyone is doing it differently}

Despite increased attention, coaching in general has yet to achieve formal and consistent professional recognition (Stec 2012). A number of issues have emerged that are associated with the unregulated and inconsistent nature of the business coach training industry which is characterised by a lack of standardisation. These challenges relate to the coach training provider, the coaching curriculum and the learner coach wishing to practise as a business coach, as well as related ethical issues for both the industry and the practitioner.

The profession attracts both pioneers and mavericks because of the high financial stakes present. Critical observers such as Laff (2007) question whether the growth of business coaching training institutes is driven by the educational needs to train individuals or simply as a means of attracting revenue. Business coach training and certification seem to be high on the list of potential revenue streams for organisations and academic departments alike (Stec 2012).

Business coaching appeals to both professionals and laypersons. The industry attracts people from diverse backgrounds. These backgrounds include retired or retiring executives, academics, trainers, engineers, senior police officers, teachers, nurses, psychologists, counsellors, psychotherapists and sport coaches. Rettinger (2011) cautions that the multidisciplinary background not only enhances the credibility of coaching as a new and emerging discipline, but could also pose challenges. One such challenge is that it leads to the coexistence of a wide variety of methods and approaches. The variety of individual backgrounds also influences the training provided as the providers often base their training on their own (often unexamined) educational background or preference. According to Grant and O'Hara (2009), some trainers have no qualifications at all. This leads to a diverse educational approach without a common understanding of expertise or educational practice. For Laff (2007), the irony is that many individuals who develop curricula are not certified. Others may be certified coaches, but may not have an educational background in designing curricula. Cohen (quoted in Laff 2007) believes that there is enough material to create a curriculum, but remains sceptical about the business coaching institutions because the intellectual rigour needed for the development may be absent.

The issue regarding the content of business coach training programmes remains contentious at best. There seems to be common agreement on the critical knowledge, skills and attitudes of business coaches such as knowledge of coaching, business and people, critical thinking skills and ethical practices (Anon 2012; Stout Rostron 2009; Zues \& Skiffington 2002), as well as the importance of facilitating these competencies during coach training programmes. However, according to Scott (2008), the delivery methods matter less than the actual content during the training of coaches. Openess to learning, self-knowledge, learning over time and the relationships in the business coaching training process are of paramount importance (Scott 2008). Redshaw (2000), however, criticises the manner in which providers set out to 'teach' coaching in general. This author challenges the didactic approach because of the view that coaching cannot be taught. Coaching is coached, which means that any activity intended to develop coaches must be designed 
in such a way that it follows and demonstrates coaching principles, allowing participants to learn for themselves.

An ongoing debate in general coaching literature has been the role of psychology or training in psychology in coaching. The same may apply to business coach training as the person remains central to the process of coaching. According to Clutterbuck (2008), a basic understanding of psychology is necessary to manage and work within boundaries. Naughton (2002) believes that most coaching programmes and imitations do not provide students with sufficient grounding in developmental psychology, interviewing techniques and other elements basic to sound therapy. Berglas (2002) argues that coaches who lack rigorous psychological training do more harm than good. Although coaching is not therapy, both coaching and therapy effect behavioural change. Understanding a client's cognitive and emotional reactions and how these may interfere with personal effectiveness, performance and wellbeing may be useful to the coach (De Haan 2008). A background in psychology may equip the coach with insight and motivation of others, adult development, effective listening skills, understanding and managing resistance and ethical practice issues such as confidentiality (Peltier 2001). Bono et al. (2009) found that the differences between the practices of psychologists and nonpsychologists were generally relatively small and suggested that it might be time to move the debate toward what we can expect coaches from different backgrounds to do best and what type of training would help all coaches to be more effective. Newnham-Kanas, Irwin and Morrow (2011) and Grant and O'Hara (2009) have added their voice most recently to the debate by recommending that coach training schools consider incorporating into their training curriculum a mental health scope of practice.

Even for those who advocate psychological training for business coaches, there is recognition that business coaching is no place for those with a background in psychology but with no interest or understanding of business (Foxhall 2002). Locally, professional executive business coaches, such as Italia Boninelli (Hamlyn 2004), stated that a number of individuals, who professed to be business coaches, had little practical expertise in business and even less insight into any of the theoretical people skills. Peltier (2001) cautions that a coach who attempts to provide coaching without significant knowledge of the business world or the corporate environment, including its bottom-line orientation, motivations and assumptions, is destined to fail. Ahern (2005) and Wasylyshyn (2003) take the middle road by stating that business coach training should focus on both psychological insight and business or organisational expertise.

Bono et al. (2009) suggest that most coach training programmes have gaps. Clinical psychology focuses on human development, but typically lacks coursework relating to the business environment or employment law. Industrial psychology programmes have a stronger focus on employee behaviour, motivation, attitudes and performance as well as the legal issues surrounding employment, but they typically do not train students in the techniques associated with one-on-one coaching or counselling. Coach certification programmes may provide the business and marketing skills needed by coaches but, owing to their brevity, cannot provide trainees with a strong foundational knowledge of human motivation and behaviour. Liljenstrand and Nebeker (2008) found that the curriculum of non-academic coaching programmes lacked consistent content and many coaches did not participate in training programmes.

Few programmes actually communicate their philosophical roots. When the roots are mentioned, it is clear that they are often based on Western traditions. Alliances are most often with organisations in the United States of America and Europe. Horwitz and Jain (2008) call into question the appropriateness of the adoption of Western management principles and practices with little consideration of the suitability and relevance of such practices to the local context. The business coaching training industry should be equally wary of the purely Eurocentric views expressed in their training programmes in the African context.

The lack of standardisation gives rise to a myriad of ethical dilemmas that can tarnish the business coaching training profession. At present, there are no real barriers to entry (Bluckert 2004) and anyone can claim to be a business coach or a coach training provider. According to Liljenstrand and Nebeker (2008), the only real barrier to entering business coaching is the coach's (or coach training provider's) ability to solicit clients. Van der Sandt (2004) posits that the low barrier to entry will impact negatively on the quality of coaching provided. Organisations wishing to register with COMENSA neither have their personal or training credentials checked, nor are their programmes assessed for any theoretical or empirical basis. The business of coach training and certification by self-appointed bodies is difficult to assess at best (Sherman \& Freas 2004) and is often dubious. From a practice perspective, coaches from different educational backgrounds may have different standards and definitions of ethical behaviour.

Although business coaching may be an emerging profession in South Africa, we can no longer afford to send people into the field as business coaches without clear entry requirements, descriptive and accepted standards, agreed-upon core competencies and accredited programmes that offer depth in terms of knowledge, skills and ethical values. From the author's perspective and experience, training programmes for business coaching need to be placed within and guided by the contextual realities in South Africa. Context shapes the nature of knowledge, learning and doing, requiring that we consider contextual factors when designing and delivering business coach training programmes. To this end, we need to engage with coaching industry stakeholders such as trainers, business owners, organisations and those receiving coaching to explore their views and needs in order to develop contextually relevant programmes. Conceptual frameworks are needed to explore and describe the gestalt (the essence of an entities complete form) and the interaction of the aspects in forming the whole. 
In the light of the above challenges, the following research questions arose:

- What matters during business coaching training programmes?

- What would an emerging conceptual framework for business coach training consist of?

The overall purpose of this research was to explore and describe an emerging conceptual framework for business coach training programmes that would be relevant in the South African context.

\section{Research method and design Research paradigm}

Appreciative inquiry (AI), located in social constructionism, formed the paradigmatic foundation for this research. Social constructionism is an approach to human science inquiry and practice characterised by a relational focus emphasising the notion that the world people were creating in the process of social exchange constituted their reality (Gergen, Gergen \& Barrett 2004).

\section{Research approach}

A generic qualitative, explorative, descriptive design was used to describe and understand the needs of business coaching stakeholders (Plano Clark \& Creswell 2010). Since there was limited coaching research literature to delve into, and little was known about the phenomenon, a qualitative design was found to be the most appropriate (Brink \& Wood 1998). The aim was not to measure and observe variables but to build a complex and holistic picture by means of the analysis of words and the reporting of the specific views of business coaching stakeholders (Corbin \& Strauss 2008).

The research was ideographic and contextual (Johns 2001). Following the initial inductive point of departure, a deductive approach was employed in order to develop an emerging conceptual framework for business coach training programmes. The conceptual framework was designed by utilising the organising principles of Dickoff, James and Wiedenbach (1968).

\section{Research setting}

The research was conducted in two countries, namely South Africa and Swaziland, since the researcher had access to and was coaching in these countries. Various industries were represented, namely the hospitality industry; retail; marketing and sales; travel; and human capital services.

\section{Establishing researcher roles}

According to Rubin and Rubin (1995), qualitative researchers frequently select interviewees according to social networks. In this case, the researcher included interviewees according to social and professional networks, as well as utilising internet searches in order to identify possible participants. In qualitative research, the researcher is the primary instrument of data collection (Creswell 2003). In order to prepare himor herself, he or she has to have engaged in thorough selfexamination, as well as having mastered interpersonal and communication skills (Greef 2011). To this end, because the researcher is also a business coach, she did a personal naïve sketch (Giorgi 1985) in order to bracket her experience and create self-awareness.

\section{Research participants}

The target population in this research was identified as follows: firstly, coaches who had experience in business coaching or business coach training; secondly, chief executive officers (CEOs) who employed the services of business coaches; and thirdly, managers who participated in business coaching. The input of the CEOs was of great importance, since they would ultimately employ or make use of the services of the business coach. Executives and managers were included because they were often the recipients of business coaching. They had experienced business coaching and their experiences, either positive or less positive, could give valuable insight into the competencies they expected from a business coach.

The total number of participants in this research was 30 . Their ages varied between 27 and 60 years. Of the 30 participants, 12 were coaches. Eight coaches were qualified advanced business coaches, whilst three of them enjoyed international recognition. They differed in race and gender. Of these 12 coaches, 10 were white and two were black, whilst four were men and eight were women. Five participants were CEOs. The ages of these CEOs varied between 34 and 50 years, and they were all white men. Six participants were general managers. The ages of these general managers varied between 35 and 53 years, and all were white men. Seven participants were managers. The ages of these managers varied between 31 and 48 years and all were Black people, with 4 men and 3 women in the group.

\section{Sampling}

Purposive sampling (Strydom 2011a, 2011b) was used to ensure that specific elements were included in the sample. Such an approach employed a considerable degree of selectivity. Purposive sampling proved useful since sampling for proportionality was not the primary concern in this research. Snowball sampling was also used (Strydom 2011a, $2011 b)$, that is, one member of a group referred the researcher to another member or coach who met the inclusion criteria for this study.

\section{Data collection methods}

In qualitative research, the researcher is the primary instrument of data collection (Creswell 2003). The researcher is a qualified business and life coach with a doctoral degree in a health science discipline. The researcher collected the data personally during:

- three focus group interviews (lasting between 45 and 90 minutes, and the number of participants were between four and seven at a time) 
- eight in-depth (Greeff 2011) individual interviews (lasting between 35 and 60 minutes)

- 13 naïve sketches (ranging from one to five pages).

The researcher's own autoethnographic naïve sketch was included. This personal memoir afforded the researcher an opportunity to reflect on personal beliefs and experiences, attitudes, educational partiality and potential biases that may have influenced the data collection, analysis and interpretation.

\section{Data analysis}

The researcher conducted a thematic analysis (Tesch, quoted in Creswell 2003) in the following manner:

- The most information-rich interview was selected and examined to determine what the data were about and to establish the underlying meaning.

- Thoughts that came to mind were recorded by compiling notes.

- The ideas were converted into topics that reflected their meaning.

- Similar topics were clustered together and recorded into columns that were arranged into major topics, unique topics and exceptions.

- The most descriptive labels for the topics were selected.

- The topics were defined and grouped into main themes and categories.

- A set of clean data were provided to an independent coder who was experienced in qualitative data analysis and business coaching education in the capacity of an external verifier.

- A consensus discussion was held between the researcher and the independent coder to verify the findings.

\section{Trustworthiness}

In qualitative designs, validity and reliability are described by strategies for trustworthiness. This research operationalised the strategies of credibility, applicability, dependability and confirmability as described by Guba (1981). Credibility was ensured by prolonged engagement, triangulation (data collection methods, participants), pee $\mathrm{r}$ debriefing and member checking. A dense description of the background information and purposive sampling ensured the transferability of this research. Dependability was maintained by code-recode procedures. Confirmability was established by means of triangulation and reflectivity.

\section{Ethical considerations}

In this study, the following ethical considerations (Strydom 2011a, 2011b) were taken into account:

- Consent to conduct research was requested and granted by the CEOs of all the business institutions that were approached.

- The CEOs acted as gatekeepers for the organisations.

- Informed consent was obtained from all participants by means of a letter communicating the necessary information pertaining to the research.
- Confidentiality was maintained and the participants were informed of the rationale, recording and safekeeping of audio recorded interviews and transcriptions.

- Participation was voluntary.

- Ethical clearance was granted by the University of Johannesburg.

\section{Results and discussion: Findings and the emergent conceptual framework}

The findings are conceptualised and reported in the emergent conceptual framework. Participants' responses are in italics. The conceptual framework utilises the six aspects of activity as an organising principle described by Dickoff et al. (1968). The six aspects of activity refer to the agent, recipient, context, dynamics, procedure and outcome or destiny. The conceptual framework presents a context-specific, systematic view of the research phenomenon by describing the relationships between these concepts. The agent refers to the people who actualise the outcome of business coach training, for example, the coach educator. The recipient refers to the coach learner and the context to the environment of the South African education context, whilst the dynamics explore the energy that ignites business coach training. The procedure emphasises either the path or steps that need to be performed in order to achieve the outcome, namely either the destiny or accomplishment of business coach training that produces competent business coaches.

Table 1 reflects the central concepts of the conceptual framework. Each concept is described below as a building block leading to a description of the emerging conceptual framework for business coach training programmes. Figure 1 provides a graphic representation of the framework.

\section{The business coach educator}

As a coach educator, the person acts as a role model, mentor and agent of change for the learner. As such the business coach educator should understand and demonstrate the core competencies of a business coach. Participants felt that the following knowledge, skills and attitudes or values were essential: 'coaching process, leadership practice, management development, business acumen, training and development, individual and group behaviour, diversity management and research methodology.' The competencies are generally in line with those suggested by the competence frameworks of

TABLE 1: Organising principles of Dickoff, James, and Wiedenbach (1968).

\begin{tabular}{ll}
\hline Description & Principles \\
\hline Agent & Business coach educator \\
Recipient & Business coach learner \\
The educational context & Statutory demands and diversity \\
Dynamics & $\begin{array}{l}\text { An appreciative philosophy } \\
\text { Procedure }\end{array}$ \\
$\begin{array}{l}\text { Progressive broadening of knowledge and skills } \\
\text { within an OBE model }\end{array}$ \\
Outcome & Competent business coach \\
\hline
\end{tabular}

Source: Adapted by author from Dickoff, James, and Wiedenbach (1968) 


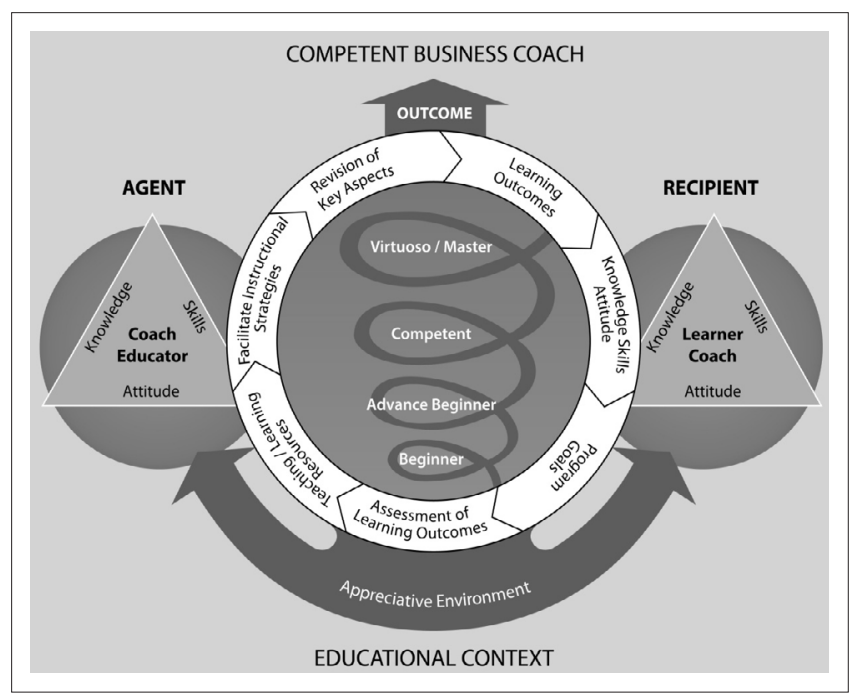

Source: Author's own construction

FIGURE 1: Conceptual framework for business coaching training.

the ICF, WABC, EMCC and COMENSA, with the exception of diversity management and research methodology.

In line with the debates in literature, the participants did not agree on the importance of a background in psychology and / or business. One participant noted the following: ' ... maybe it is that rare combination of a person with a psychology background together with a business qualification of sorts, to equip this person to understand how this game of business is being played.' According to Hall and Duval (2004), the coach or, in this instance, the business coach educator, may not be the expert and have all the experience, but he or she knows structure and process and is an expert at coaching.

An additional knowledge competency referred to knowledge of research methodology. 'How are we going to develop the field if we don't do research and publications ... you have to have written two or three articles, a mini-dissertation, spoken at a national or international conference. That would distinguish you from any other level of coaching.' Knowledge of research methodology was suggested at the master's level of the business coach training programme.

One of the emerging disciplines in coaching is research (Stout Rostron 2009). A new approach is to consider all coaches as being potential contributors to the emerging body of coaching knowledge. The type of research many coaches may be concerned with could be described as practicebased research (Candy 2006), meaning that the research has relevance, usually by direct application, to coaching practice. A business coaching practice-based research project will usually focus on improving business coaching practice or developing coaching theory and will have a specific business coaching-related practice outcome. For a business coach to become a potential contributor to the emerging body of knowledge, three specific skills are needed: a critical reading of research, an application of research to practice and the capacity and ability to generate research (Stout Rostron 2009). The business coach educator should have the background and competence to facilitate this learning.
Learning is never only cognitive - attitudes and values go hand in hand with intellect (Van der Horst \& McDonald 1997). Having the right attitude and living up to values are of fundamental importance and need to be modelled during the business coach training process. The following core attitudes and values were identified: 'authenticity, self-awareness, openness, honesty and integrity, respect, ethical ways of being, empathy, trust, enthusiasm and passion, inspiration, as well as resilience.' Self-awareness and the importance of relationships tie in with the findings of Scott (2008). Meyer and Fourie (2004) support the notion that coaches (in this context, business coach educators) should have a sound knowledge of human relations and the behaviour of individuals and groups.

The business coach educator is not merely a presenter of knowledge, but in fact a facilitator of the learner's learning process. A business coach educator stated that 'facilitation skills, how to facilitate, understanding learner dynamics' are needed. A facilitator requires a totally different set of skills compared with a teacher (Cooper 2006). A facilitator asks questions, provides guidelines and creates the environment for the coach learner to draw his or her own conclusions.

As in a coaching session with a client, the business coach educator crafts powerful outcomes as the way forward in accepting personal learning in the educational setting. One CEO commented as follows: 'the important thing about coaching is that you have measurable outcomes ... so that you are not sucked in by that dynamics and nothing happens.' The business coach educator and the learner share the responsibility for and control of the learning process. The educator focuses on the learner and his or her needs and acknowledges human diversity in order to allow all learners to achieve their full potential. To achieve this, the educator is responsible for creating and controlling the facilitative context and the conditions that are conducive to learners' success. This context includes a climate of physical and psychological safety, motivation, challenge and invitation, bringing about honest interaction, engaged learning and opportunities for the application of knowledge in real-life business environments.

The responsibility of the business coach educator extends beyond the routine scheduling of activities to a penetrating analysis of higher aspirations and the changes required to achieve them, the diagnosis of obstacles that should be overcome in achieving these changes and the planning of effective strategies for accomplishing the desired results.

\section{The learner coach as recipient}

Because learner coaches are adult learners, they are capable of self-directed learning, taking responsibility for their own learning and critical thinking. One business coach educator noted the following: 'the principles of adult education are essential in a programme for coaches, they must appreciate that adult learning has a different approach and different assumptions.' This is in line with O'Flaherty and Everson's 
(2005) assertion that andragogic principles work well in the context of coaching. Adults see education as a process of developing increased competence to achieve their full potential in life. They want to be able to apply the knowledge and skills immediately (Knowles 1980).

Adults have an ever-increasing reservoir of experience that becomes a rich source of learning for themselves and others. They therefore attach more meaning to learning because they gain from experience instead of acquiring knowledge passively. Adult are ready to learn when they experience a need to learn in order to cope with a more satisfying real-life task or problem (Knowles 1980).

The outcome of the business coach training programme will see the learner coach develop the requisite knowledge, skills and attitudes or values as discussed for the business coach educator.

\section{The educational context}

All education and training in South Africa forms part of the NQF adopted by the South African Qualifications Authority (SAQA n.d.). The NQF objectives encapsulate a number of key principles. Access constitutes one of the quality indicators and is described as providing ease of entry to an appropriate level of education and training for all prospective learners in a manner that promotes progression (Coetzee 2002).

One participant referred to access at entry levels as follows: 'There should be different entrance levels.'

Another participant stated that '... an entry level should be there but there should also be recognition of prior learning.'

Recognition of prior learning is an NQF key principle and refers to giving credit to learning which has already been acquired in different ways, for example, through life experience and after an assessment of the learning (Coetzee 2002). One participant mentioned the following example: 'this could mean bringing a video tape where you assisted people in a time span of two hours to take effective decisions.'

Selection criteria received some attention but remained a 'difficult thing.' 'There should be selection criteria.' Another participant suggested taking 'business experience into consideration, they must have been in a management position.' This ties in with recognition of prior learning. 'Interviewing prospective coaches' was mentioned as well as 'psychological testing'. The problem with psychological testing is that 'no psychological test is context sensitive ... people go through hundreds of contexts every day, they also generalise ...'.

Literature on psychometric testing in the workplace states that 'psychometric tests are relied on too much' (April 2005/2006:39). This author feels that many candidates could potentially be overlooked because their psychometric tests do not match perfectly the theoretical psychological profiles that seem to be required. The value of psychological tests is not completely discarded, but should be viewed along with a candidate's track record and results of the interview. 'We should think about developing that person's weakness rather than dismissing him or her as unsuitable.'

South Africa is a diverse society in terms of ethnicity, culture, communication, thinking and learning styles (Stout Rostron 2009). These all impact on the business coach training process and programmes. One participant said that it is necessary 'to understand where people come from ... their culture, their circumstances ...'. Another participant cautioned: 'Something else that should be addressed is the issue of diversity ... they've got [to understand] that you get diverse information, people ... but don't always hide behind this curtain of culture ...'.

Understanding how diversity impacts on coaching is a crucial element of effective coaching (Passmore 2013). The business coach industry attracts prospective coach learners from diverse backgrounds, ages and professions. Gurin et al. (2002) suggest that programme developers design training programmes that make the most of the learners' diverse perspectives and backgrounds. The educational context should foster active thinking, intellectual engagement and democratic participation. In addition, a supportive environment is needed in which disequilibrium and experimentation can occur by increasing interaction between diverse peers.

Given the disparity of learner coaches' academic preparation (Grant \& O'Hara 2009), teaching and learning should be contextualised by providing instruction relating directly to the life experiences or functional contexts of the business coach learner. The Center for Student Success (2009) found that there is a positive impact of contextual teaching and learning on learner behaviour, performance, persistence and achievement in coursework and employment.

Learning does not occur only in a classroom or workshop setting. Creating an environment conducive to transformational learning involves the long-term commitment of all stakeholders (such as industry, education and professional bodies) to continuous growth and learning.

\section{The dynamics: An appreciative environment}

The dynamics explore the drive that ignites and maintains the business coach training programme.

\section{Appreciative philosophy}

One manager noted that the business coach or coach educator has to have an appreciation for people and organisations. Don't just hammer on what is wrong. Look what is right and also work on that.' Business coach training programmes could consider Appreciative Inquiry (AI) as an approach to 
embrace this request. $\mathrm{AI}$ is a cooperative search for the best in people, their organisations and the world around them. It is based upon an AI philosophy that embraces the assumption that every living system has a hidden and underutilised core of strengths. Its positive core, when revealed and tapped, provides a sustainable source of positive energy for transformation (Cooperrider \& Whitney 2005). AI has been criticised for being naïve and idealistic in the way it focuses on positive experiences or ignores or supresses accounts of negative experiences (Reed 2007). In a study in a conflicted educational context, McNamee (2003), however, found that problems of weaknesses were often much easier to address when evaluation occurs from an appreciative perspective.

\section{The programme procedure}

The programme procedure includes the cyclic outcomesbased education (OBE) model and encapsulates the process in a progressive programme broadening mode.

\section{OBE model}

Participants, especially those with a background in education stated that 'business coach training programmes should specify the knowledge, skill and attitudes/values that the coach must achieve in order to reach the desired outcomes.' All education and training in South Africa currently uses an OBE approach. In this approach, clear statements are made about the knowledge, skill, values and attitudes that are promoted as learners engage in the learning process (Van der Horst \& McDonald 1997). According to Meyer and Fourie (2004), coaches need the right knowledge, skills and values to be successful.

The OBE model proposes a continuous cyclic process which includes the following phases: learning outcomes, knowledge, skills, attitudes and values required by the learner, programme goals, assessment of learning outcomes, teaching-learning resources and activities, facilitative instructional strategies and revision of key aspects (Van der Horst and McDonald 1997). Assessment of learning outcomes could include learning and reflective written reports (O'Flaherty \& Everson 2005) and observation or recording of real-time coaching interventions (Maritz, Poggenpoel \& Myburgh 2011). Maritz et al. (2011) suggest the following possible teaching strategies for business coach training programmes: lectures, readings, dialogue, demonstrations, analogies, metaphors and narratives, simulations, role play, case studies, one-on-one and peer coaching, reflective journals, logging reports, concept mapping, small cooperative group work projects, value clarification, research projects and coaching supervision. O'Flaherty and Everson (2005) include reflection, learning pods, real play (learning from real issues instead of hypothetical scenarios) as opposed to role play and revolving triads (consisting of a coach, coachee and an observer who all provide revolving perspectives).

\section{Progressive broadening of knowledge and skills}

Participants concurred that if a person trains [business] coaches, you would do it on different levels. The top level will be simple models, nearly do this, and do this model. Then there is a greater complexity of, there are still some favorite models, but there is thinking on your feet where you have to decide which component, which model will work best.' Progressive broadening of knowledge and skills in the business coach training programme should allow for the development of elementary concepts and skills before attempts are made to master more complicated concepts and skills. According to the NQF (SAQA n.d.), levels are arranged to indicate the increasing complexity in learning and to facilitate meaningful progression routes along learning and career pathways.

Hargrove (2003:16) proposes the following stages in a coach training programme and states the following: 'While it takes a powerful commitment to become a coach, there are different stages along the way and each must be valued.' The stages include:

- beginner (sometimes a nuisance)

- advanced beginner (does well enough under supervision).

Internationally, most advanced level coaching education is based around the university accreditation model of postgraduate certificate, diploma or full master's programmes, which take between one and three years to complete (Bluckert 2004). Bluckert argues that executive coaching competence, which embraces the following, takes considerably longer:

- competent (capable)

- virtuoso (brilliant)

- mastery (invents new rules, becomes a legend).

The components of modern business coach training programmes should become more advanced and more integrated as a coach progresses from one level to the next. According to Rodger (2011:360), 'it takes 1000 hours of practice and feedback to learn the basics, 3000 hours to deal with the mainstream of what a client brings and 10000 hours to feel that little a client can say or do will unsettle you.' This echo's Malcolm Gladwell's (2008) conclusion that it takes 10000 hours of practice to obtain the level of mastery associated with being a world-class expert in anything.

It would seem that international and local coach training programmes fall far short of this expectation. The ICF, the field' s leading certification body (ICF 2012a, 2012b), offers credentialing programmes at different levels such as associate certified coach (ACC), professional certified coach (PCC), and master certified coach (MCC). The ACC requires 100 coaching hours and the PCC 750 coaching hours. Certification as an MCC requires 2500 coaching hours.

A number of local organisations offer business coach training programmes ranging from two days to 18 months in length. These training programmes often require as little as six or nine coaching sessions, amounting to six to nine practice hours at best. The buyers of business coach training should realise that not all training is equal and not all programmes may deliver competent business coaches. 


\section{The outcome of the activity}

An outcome refers to the contextually-demonstrated endproduct of the learning process (Coetzee 2002). The outcome of the activity or programme is to deliver a competent business coach who practises both ethically and competently, based on appropriate professional experience and business knowledge, and who has an understanding of individual and organisational change and diversity. The business coach should be able to communicate effectively and facilitate the learning process and results of individuals and business organisations (Stout Rostron 2009).

\section{Theoretical and practical implications}

The emerging conceptual framework for business coach training programmes attempts to fill the empirical void in existing business coaching pedagogy by providing an empirical account of what business coaching stakeholders view as being important in business coach training programmes. The framework may be utilised in business coach training practice to guide curriculum development and implementation. A unique aspect of the framework is found in its contextual location in the South African business environment.

\section{Recommendations}

It is recommended that the framework be refined once it has been implemented in business coaching curricula.

\section{Summary and conclusion}

This research was conducted in order to understand what matters during business coach training programmes. The findings were conceptualised and described with regard to the business coach educator as a role model and facilitator of learning, the coach learner as an adult learner and the educational context. An appreciative environment was recommended. The procedure suggested a progressive broadening of knowledge and skills in an OBE model. The outcome envisioned a competent business coach who practises both ethically and competently.

Because of the increasing demand for business coaching, the coaching industry needs to respond by providing credible and competent business coaches. International and local collaboration is vital with regard to the facilitation of global dialogue in order to understand the needs of business coaching consumers, practitioners and educators.

\section{Acknowledgments Competing interests}

The author declares that she has no financial or personal relationship(s) which may have inappropriately influenced her in writing this article.

\section{Author's contributions}

J.M. (University of South Africa) was responsible for the conceptualisation and implementation of the research.

\section{References}

Ahern, G., 2005, 'Coaching professionalism and provider size', Journal of Management Development 24(1), 94-99. http://dx.doi.org/10.1108/02621710510572371

Anon., 2012, 'Coaches and Mentors of South Africa (COMENSA), viewed 18 December 2012, from http://www.comensa.org.za/

April, K. 2005/2006, Psychometric tests relied on too much, Business Brief 10(6), December/January, 38-43.

Auerbach, J.E., 2005, Seeing the light: what organisations need to know about executive coaching, Executive College Press, Pismo Beach, CA.

Berglas, S., 2002, 'The very real dangers of executive coaching', Harvard Business Review, June, 87-92.

Bluckert, P., 2004, 'The state of play in corporate coaching: current and future trends', Industrial and Commercial Training 36(2), 53-56. http://dx.doi. org/10.1108/00197850410524806

Bono, J.E., Purvanova, R.K., Towler, A.J. \& Peterson, D.B., 2009, 'A survey of executive coaching practices', Personnel Psychology 62(2), 361-404. http://dx.doi. org/10.1111/j.1744-6570.2009.01142.x

Bresser, F., 2009, 'Business coaching on the rise across the globe', viewed 18 December 2012, from http://www.frank.bresser-consulting.com/globalcoachingsurvey.htm

Brink, P.J. \& Wood, M.J., 1998, Advanced design in nursing research, Sage, Thousand Oaks, CA

Butler, D. \& Forbes, B., 2008, 'An examination of a skills-based leadership coaching course in an MBA program', Journal of Education for Business 83(4), March/April, 227-232. http://dx.doi.org/10.3200/JOEB.83.4.227-232

Candy, L., 2006, 'Practice based research: a guide', viewed 28 December 2012, from http://www.creativityandcognition.com/resources/PBR\%20Guide-1.1-2006.pdf

Clegg, S.R., Rhodes, C., Kornberger, M. \& Stilin, R., 2005, 'Business coaching: challenges for an emerging industry', Industrial and Commercial Training 37(5), 218-223. http://dx.doi.org/10.1108/00197850510609630

Clutterbuck, D., 2008, 'What's happening in coaching and mentoring? And what is the difference between them?', Development and Learning in Organizations 22(4), 8-10. http://dx.doi.org/10.1108/14777280810886364

Coaches and Mentors of South Africa (COMENSA), 2012a, 'National President's yearend report', Electronic mail.

Coaches and Mentors of South Africa (COMENSA), 2012b, 'Business coaching', viewed 11 January 2013, from http://www.comensa.co.za/PROFESSIONAL_PRACTICE/ Business-Coaching.aspx

Coetzee, M., 2002, Getting and keeping your accreditation, Van Schaik, Pretoria.

Cooper, J., 2006, 'Training for tomorrow', HR Future, January, n.p.

Cooperrider, D.L. \& Whitney, D., 2005, Appreciative inquiry a positive revolution in change, Berrett-Koehler, San Francisco.

Corbin, J. \& Strauss, A., 2008, Basics of qualitative research, 3rd edn., Sage, Los Angeles.

Creswell, J.W., 2003, Research design, 2nd edn., Sage, Thousand Oaks, CA.

De Haan, E., 2008, 'Becoming simultaneously thicker and thinner skinned', Personnel Review 37(5), 526-542. http://dx.doi.org/10.1108/00483480810891664

Dickoff, J., James, P. \& Wiedenbach, E., 1968, 'Theory and practice discipline: part 1. Practice orientated theory', Nursing Research 17(5), 415-435. http://dx.doi org/10.1097/00006199-196809000-00006, PMid:5186886

e.releases, 2012, 'Partnership leads to creation of the global coaching and mentoring alliance', viewed 21 December 2012, from http://www.ereleases.com/pr/ partnership-leads-creation-global-coaching-mentoring-alliance-92155

Foxhall, K., 2002, 'More psychologists are attracted to the executive coaching field', Monitor on Psychology 33(4), 50-53.

Gentry, W.A., Mondore, S.P. \& Brennan, D.C., 2007, 'A study of managerial derailment characterisitcs and personality preferences', Journal of Management Development 26(9), 857-873. http://dx.doi.org/10.1108/02621710710819348

Gergen, M.M., Gergen, K.J. \& Barrett, F., 2004, 'Appreciative inquiry as dialogue: generative and transformative', in D.L. Cooperrider \& M. Avital (eds.), Advances in appreciative inquiry: constructive discourse and human organization, Vol $1, \mathrm{pp}$ 3-27, Elsevier, Amsterdam.

Giorgi, A. (ed.), 1985, Phenomenology and Psychological Research, Duquesne University Press, Pittsburgh.

Gladwell, M., 2008, Outliers, Penguin, London.

Grant, A.M., 2004, 'Keeping up with the cheese: research as a foundation for professional coaching of the future', in I.F. Steyn \& L.A. Belsten (eds.), Proceedings of the First ICF Coaching Research Symposium, pp. 1-19, Washington.

Grant, A.M. \& O'Hara, B., 2009, 'Key characterestics of the commercial Australian executive coach training industry', International Psychology Review 3(1), 57-73.

Greef, M., 2011, 'Information collection: interviewing', in A.S. de Vos, H. Strydom, C.B. Fouche \& C.S. Delport (eds.), Research at grass roots, 4th edn., pp. 341-375, Van Schaik, Pretoria.

Guba, E.G., 1981, 'Criteria for assessing the trustworthiness of naturalistic inquiries', Educational Resources Information Center Annual Review 29(2), 75-91.

Gurin, P., Dey, E.L., Hurtado, S. \& Gurin, G., 2002, 'Diversity and higher education: theory and impact on educational outcomes', Harvard Educational 72(3), 1-26. 
Hall, L.M. \& Duval, M., 2004, 'Neurosemantic coaching for the next generation executives', HR Future January, 4-6.

Hamlyn, J., 2004, 'Executive personal coaching', HR Future May, 28-29.

Hargrove, R., 2003, Masterful coaching, Revised edn., Jossey-Bass, San Francisco.

Hillary, D., 2003, 'Executive coaching', HR Future, 10-11.

Horwitz, F.M. \& Jain, H.C., 2008, 'Managing human resources in South Africa: a multinational firm focus', Advances in International Management 21, 89-123. $\mathrm{http}: / / \mathrm{dx}$.doi.org/10.1016/S1571-5027(08)00004-1

International Coaching Federation (ICF), 2011a, 'Accreditation', viewed 30 December 2012, from http://www.coachfederation.org/icfcredentials

Johns, G., 2001, 'In praise of context', Journal of Organizational Behaviour 22(1), 3142. http://dx.doi.org/10.1002/job.80

Kelman, S., 2010, 'Workforce morale can be sapped by unskilled managers', viewed 18 December 2012, from http://fcw.com/articles/2010/09/13/comment-stevekelman-federal-supervisors.aspx

Knowles, M.S., 1980, The modern practice of adult education: from pedagogy to andragogy, Association Press, Chicago.

Laff, M., 2007, 'The certified coach: a brand you should be able to trust', Training and Development April, 39-48.

Liljenstrand, A.M. \& Nebeker, D.M., 2008, 'Coaching services: a look at coaches, clients and practices', Consulting Psychology Journal 60(1), 57-77. http://dx.doi. org/10.1037/1065-9293.60.1.57

Maritz, J.E., Poggenpoel, M. \& Myburgh, C.P., 2011, 'Exploring teaching strategies for training programmes in business coaching', Acta Academica 43(4), 152-180.

McNamee, S., 2003, 'Appreciative evaluation within a conflicting educational context', New Directions for Evaluations 100, 23-40. http://dx.doi.org/10.1002/ev.97

Meyer, M. \& Fourie, L., 2004, Mentoring and coaching, Knowres, Randburg.

Moore, A., 2007, 'The qualification game', Training and Coaching Today, May, 27.

Naughton, J., 2002, 'The coaching boom', Psychothera July/August, 24-33.

Newnham-Kanas, C., Irwin, J. \& Morrow, D., 2011, 'Findings from a global survey of certified professional co-active coaches', International Journal of Evidence Based Coaching and Mentoring $9(2), 23-36$

O’Flaherty, C.M. \& Everson, J.M., 2005, 'Equiping leaders to coach: an androgogic learning model', paper presented at the Eleventh International Eastern Academy of Management Conference on Managing in a Global Economy proceedings, June, of Management Conference on Manag
Cape Town, South Africa, pp. 372-397.

O'Shaughnessy, S., 2001, 'Executive coaching: the route to business stardom', Industrial and Commercial Training 33(6), 194-197.

Passmore, J., 2013, Diversity in coaching: international approaches to working with gender, culture, race and age, 2nd edn., Kogan Page, London.

Peltier, B., 2001, The psychology of executive coaching, Brunner-Routledge, New York.

Plano Clark, V.L. \& Creswell, J.W., 2010, Understanding research: a consumer's guide, Merrill, Boston.

Redshaw, B., 2000, 'Do we really understand coaching?', Industrial and Commercial Training 32(3), 106-108. http://dx.doi.org/10.1108/00197850010371693
Reed, J., 2007, Appreciative inquiry, Sage, Thousand Oaks, CA.

Rodger, J., 2011, 'Afterword challenges ahead', in L. Wildflower \& D. Brennan (eds.), The handbook of knowledge based coaching, pp. 341-344, Jossey-Bass, San Fransisco, CA.

Rothgiesser, S., 2004, 'Coaching for better performance', Executive Business Brief, August/September, 52-53.

Rettinger, S., 'Construction and display of competence and (professional) identity in coaching interactions', Journal of Business Communications 48(4), 426-445.

Rubin, H.J. \& Rubin, I.S., 1995, Qualitative interviewing, Sage, London.

Scott, H.L., 2008, 'Optimal delivery of coach training for holistic business and personal tele-coaching', Published dissertation, Gonzaga University, Washington.

Sherman, S. \& Freas, A., 2004, 'The wild west of executive coaching', Harvard Business Review November, 82-90.

Smith, A., Van Vuuren, L.J. \& Visser, D., 2003, 'Client-consultant ethical relationship considerations with management consulting', South African Journal of Industria Psychology 29(1), 83-92.

South African Qualifications Authority (SAQA), n.d., 'Level Descriptors for the South African National Qualifications Framework', viewed 28 December 2012, from http://www.nqf.org.za/download_files/level_descriptors.pdf

Stec, D., 2012, 'The personification of an object and the emergence of coaching', Journal of Management History 18(3), 331-358. http://dx.doi. org/10.1108/17511341211236273

Stout Rostron, S., 2009, Business coaching wisdom and practice, Knowres, Randburg.

Strydom, H., 2011a, 'Ethical aspects of research in the social sciences and human service professions', in A.S. de Vos, H. Strydom, C.B. Fouche \& C.S. Delport (eds.) Research at grass roots, 4th edn, pp. 113-130, Van Schaik, Pretoria.

Strydom, H., 2011b, 'Sampling in the quantitative paradigm', in A.S. de Vos, H. Strydom, C.B. Fouche \& C.S. Delport (eds.), Research at grass roots, 4th edn, pp. 223-235, Van Schaik, Pretoria.

The Center for Student Success, 2009, 'Contextualized teaching and learning: a faculty primer', viewed 28 December 2012, from http://www.cccbsi.org/Websites/ basicskills/Images/CTL.pdf

Tuck, M., 2004/5, All about human capital development, 2nd edn., WriteStuff, Sandton.

Van der Horst, H. \& McDonald, R., 1997, Outcomes-based education: a teacher's manual, Kagiso, Pretoria.

Van der Sandt, L., 2004, 'Executive coaching is hot, part 2', HR Future March, 26-28.

Van Jaarsveld, A., 2004, 'Managerial derailment', HR Future December, 26-27.

Wasylyshyn, K.M., 2003, 'Executive coaching: an outcome study', Consulting Psychology Journal: Practice and Research 55(2), 94-106. http://dx.doi. org/10.1037/1061-4087.55.2.94

Wilson, C., 2004, 'Coaching and coach training in the workplace', Industrial and Commercial Training 36(4), 96-98. http://dx.doi.org/10.1108/ 00197850410532087

World Association of Business Coaches (WABC), 2011, viewed 29 December 2012 from http://www.wabccoaches.com

Zues, P. \& Skiffington, S., 2002, The coaching at work toolkit, McGraw-Hill, Sydney. 